\title{
The Influence of Investor Psychology on Disposition Effect
}

\author{
Pi-Chuan Sun ${ }^{1}$, Shu Chun Hsiao ${ }^{2}$ \\ ${ }^{1}$ Associate Professor, Department of Business Management, Tatung University, \\ 40 ChungShan North Road, 3rd Section Taipei 104, Taiwan. \\ pcsun@ttu.edu.tw \\ ${ }^{2} 40$ ChungShan North Road, 3rd Section Taipei 104, Taiwan. \\ justina710717@hotmail.com.tw
}

\section{ABSTRACT}

In 1980s, many empirical researches' findings (i.e., Shiller(1984), Thaler (1985) et al. ) did not support efficient market hypothesis (EMH). Previous studies (e.g., Bernartzi and Thaler, 1995) related to behavioral model suggest that certain market anomalies are consistent with the presence of irrational trades by investors. Kahneman and Tversky (1979) proposed the prospect theory as an alternative to expected utility in describing investor behavior.

Based on previous works (Lichtenstein, Fischhoff and Phillips, 1982; Shefrin and Statman, 1985) this research examined the influences of overconfidence, mental accounting, regret aversion and self-control on the disposition effect of selling winners too early and holding losers too long. The results of empirical data analysis of 290 investors indicate that all four psychological factors have significant influences on the disposition effect. The findings show that (1) overconfidence, mental accounting and self- control positively influence the disposition effect, and (2) self-control negatively influences the disposition effect. As predicted, self control can reduce irrational behavior of investor.

Keyword: Disposition effect, Overconfidence,

Mental Accounting, Self-Control

\section{Introduction}

Traditional finance theory is usually based on efficient market hypothesis (EMH), assuming that investors are rational and the prices of securities fully reflect available information while price changes should be random. In 1980s, many empirical researches' findings (i.e., Shiller(1984), Thaler (1985) et al. ) did not support EMH. Previous studies related to behavioral model suggest that certain market anomalies are consistent with the presence of irrational trading by investors. However, most of studies were based on the overall market data. There is little research focusing on the empirical study of the effects of psychological factors. This study will examine investors' decisions to realize gains and losses in a market setting. Specifically, the attention is focused on the stock market and seeks to determine the influence of investor psychology on the disposition effect. Four psychological factors suggested by former researches are concerned in this study. These four factors include overconfidence (Lichtenstein, Fischhoff and Phillips, 1982), mental accounting, regret aversion and self-control (Shefrin and Staman, 1985). The question of this study is whether these four factors really affect the disposition effect and the objectives of this study are to examine the influences of these four factors on the disposition effect.

The rest of our paper is structured as follows. In section 2, we provide a conceptual foundation for our model and hypotheses. In Section 3, we explain our research methodology and analysis. Section 4 presents discussion and implications of the study finds. In section 5, we suggested limitations of the study along with suggestions for future research.

2. Conceptual framework and Hypotheses

\subsection{Prospect Theory}

Prospect theory explains how decision makers actually behave when confronted with choice under uncertainty and formalizes an S-shaped value function to substitute for expected utility function of expected utility theory. Prospect theory is founded on two propositions. Firstly, investor utility is a function of gains and losses relative to a fixed reference point, rather than a function of the levels of wealth. Secondly, investor's utility functions are concave in the gains region and convex in the loss region. Moreover, prospect theory implies that investors employ a valuation function which reflects risk aversion in the domain of gains and risk seeking in the domain of losses.

\subsection{Disposition Effect}

The disposition effect is suggested by Shefrin and Statman (1985) to demonstrate a pervasive behavior of holding losers too long while selling winners too soon. Shefrin and Statman(1985) employed a behavioral model consisting of four elements to study the disposition effect. The four elements are prospect theory, mental accounting, regret aversion, and self-control.

\subsection{Relationship between Overconfidence and Disposition Effect}

Lichtenstein, Fischhoff and Phillips (1982) proposed that people often do the wrong judgments of the event happening probability, and comparing to the real happening times it appears to be overestimate this situation. It means that people are usually 
overconfident.

Odean (1998) pointed out that overconfidence may result from investor's overestimate of the precision of their private signals, and their knowledge about the value of a financial security. They always remember the success and easily forget the failure. Overconfidence often cause the wrong decision thus lose the chance to correct or enhance the ability to make a right decision. In summary, this study proposes hypotheses 1: Overconfidence is positively related to disposition effect.

\subsection{Relationship between Mental Accounting and Disposition Effect}

Tversky and Kahneman (1981), Thaler (1985) and Kahneman and Lovallo (1993 ) argued that investors will divide all outcome into several small parts that is several mental accountings. Thaler(1999)argued the mental accounting of paper gains and losses is tricky, but one clear intuition is that a realized loss is more painful than a paper loss. Because closing an account at a loss is painful, a prediction of mental accounting is that people will be reluctant to sell securities that have declined in value.

Shefrin and Stateman (2000) develop the portfolio theory of investment behavior based on the prospect theories of Lopes (1987) and Kahneman and Tversky (1979). They employ single account and multiple accounts to deduce the portfolio theory. Because of concerning the covariance of various stocks, investors with single account tendency will put the whole portfolio into the same account. In contrary, investors with multiple accounts tendency divided portfolio into different account and ignored the covariance. In summary, this study proposes hypotheses 2 : Mental accounting is positively related to disposition effect.

\subsection{Relationship between Regret Aversion and Disposition Effect}

Shefrin and Statman(1985) suggested regret is an emotional feeling associated with the ex post knowledge that a different past decision would have fared better than the one chosen, as one of the factors leading to the disposition effect. Baber and Odean(1999) suggested investors want to avoid regret. when investors hold the paper gains stock, investors worry about the stock price will fall, so investors sell paper gains stock to become realized gains. Conversely, when investors ride the paper losses stock, investors will expect the stock price will go up in the future, so they will ride the loss stock. Shiller (2000) argued that regret theory may apparently help explaining the fact that investors defer the selling of stocks that have gone down in value and accelerate the selling of stocks that have going up in value. Since the fear of regret leads investors to postpone losses, symmetrically, the desire for pride leads to the realization of gains. In summary, we can infer that investors might feel regret when they realize a loss, and, conversely, feel pride when they realize a paper gains. Investors expected stock price will mean reversion when investors hold losses stock, conversely, Investors worried about stock price will fall in the future when investors hold gains stock, so causing irrational behavioral. In summary, this research proposes hypotheses 3: Avoid regret is positively related to disposition effect.

\subsection{Relationship between Self-Control and Disposition Effect}

Self-control is to control one's emotion. Investor with high self-control will avoid reluctant to realize loss and realize gains. But they will also realize loss to avoid larger losses. Klenfield (1983) suggests an iron-clad rule that mandate the realization of a loss to avoid extreme loss. Investor should sell the loser once the declining reaches a predetermined percentage (e.g., ten percent) of the original purchase price.

Odean's (1998) and Grinblatt and Keloharju's(2001) results showed that investors do sell more losers near the end of a year. One possible explanation is tax-loss selling hypothesis, which is derived from the consequence of the US tax code and the tax year end of December 31. One of the properties of the US tax code is that capital losses are tax-deductible. Therefore, any losses can be offset against gains which provide a motivation for individual investors to sell stocks before the end of the current year. Selling in the December shows the function of self control. Investors can not enjoy benefit of tax-loss in Taiwan, but can use precommitment techniques to control their resistance to realizing losses. In summary, we propose hypotheses 4: Self control is negative related to disposition effect.

\section{Methodology \\ 3.1 Measurement}

Survey by questionnaires is conducted and five-point scales are anchored from strongly disagree to strongly agree. The scales are combined from several other relevant studies, such as Shefrin and Statman(1985), Kottemann, Avis and Remus(1994), Min-Hua Kuo(2005), Zhang Yuanfu (2004),Davis and Kottemann(1994) and Pereira(1999) with new items to make an initial list of questions.Before the formal investigation, a pilot test was conducted to make sue investor's understanding of each item and good reliability of scales. Thirty nine investors completed the questionnaires. Consistency of scale was measured in term of Cronbach's $\alpha$, and the results show that five scales have greater than the suggested threshold value of 0.7.It shows that all the scales display a good reliability.

\subsection{Data Collection}

The subject of this study is investors of stock market. Data is collected from four universities by 
convenient sampling. The sample consisted of EMBA students of University in Taipei. 302 students were asked to complete the questionnaires. 290 of the 302 retuned questionnaires are usable. Sixty three percent of all the respondents are male and $37 \%$ are female.

\subsection{Analysis}

Factors analysis was presented that response to the 18 -items scales were extracted 4 optimum factors. Every item's loading are over 0.5 , so there was no item to be eliminate. On the other hand, the accumulated percentage of variance is equal to $63.58 \%$, sufficient to represent the original data.

To assess the reliability of the study constructs, we used Cronbach's alpha. The Cronbach's alpha of each latent variable was as follows: disposition effect
(0.7549), overconfidence $(0.873)$, mental accounting (0.7549), regret aversion (0.8586), self-control (0.7817). The five scales have greater than the suggested threshold value of 0.70 . The alpha value for the four composites demonstrates adequate internal consistency.

Confirmatory factor analysis (CFA) was used to assess construct validity and dimensionality. Overall fit statistics of the measurement model were as follows: First, these loadings can be interpreted as validity coefficients reflecting the degree to which the observed variables adequately measure the specified underlying construct. Second, the confirmatory factor analysis indicated a satisfactory level of fit of the measurement model. The results presented in Table1.

Table 1 Convergent validity of independence

\begin{tabular}{|c|c|c|c|c|c|c|c|c|}
\hline Construct & Variable & $\begin{array}{l}\text { Standardized } \\
\text { Beta-Coeff. }\end{array}$ & $\begin{array}{c}\text { Constr } \\
\text { uct }\end{array}$ & Variable & $\begin{array}{l}\text { Standardized } \\
\text { Beta-Coeff. }\end{array}$ & \begin{tabular}{|c|c|} 
Const \\
ruct
\end{tabular} & $\begin{array}{l}\text { ariabl } \\
\text { e }\end{array}$ & $\begin{array}{l}\text { Standardized } \\
\text { Beta-Coeff. }\end{array}$ \\
\hline \multirow{4}{*}{ OC } & oc1 & $0.665^{* * *}$ & \multirow{7}{*}{ AR } & ar1 & $0.747^{* * *}$ & \multirow{7}{*}{ SE } & \multirow{4}{*}{$\begin{array}{l}\text { se1 } \\
\text { se2 } \\
\text { se3 } \\
\text { se4 }\end{array}$} & \multirow{4}{*}{$\begin{array}{l}0.807^{* * *} \\
0.775^{* * *} \\
0.767^{* * *} \\
0.798^{* * *}\end{array}$} \\
\hline & oc2 & $0.690^{* * *}$ & & ar2 & $0.670^{* * *}$ & & & \\
\hline & oc3 & $0.837^{* * *}$ & & ar3 & $0.645^{* * *}$ & & & \\
\hline & oc4 & $0.756^{* * *}$ & & ar4 & $0.737^{* * *}$ & & & \\
\hline \multirow{3}{*}{ MA } & mal & $0.754^{* * *}$ & & $\operatorname{ar} 5$ & $0.769^{* * *}$ & & & \\
\hline & $\mathrm{ma} 2$ & $0.826^{* * *}$ & & ar6 & $0.784^{* * *}$ & & & \\
\hline & ma3 & $0.660^{* * *}$ & & ar7 & $0.745^{* * *}$ & & & \\
\hline
\end{tabular}

To establish discriminant validity, we constructed models for all possible pairs of latent constructs. According to Bagozzi (1991) argued discriminant validity methods to test correlation between the two constructs and fix the correlation between the constructs at 1.0. A significant difference in chi-square values for the fixed and free solutions indicates the distinctiveness of the two constructs. For the four constructs, a total of 6 different discriminant validity checks were conducted. All the differences between the fixed and free solutions are significant, providing strong evidence of discriminant validity among the theoretical constructs.

\subsection{Results of analysis}

The structural equation model is conducted using AMOS 5.0 to examine path relationships. Two

Table 2 Results for the Best Fitted Model

\begin{tabular}{|c|c|c|c|c|c|}
\hline Path & Hypothesis & $\begin{array}{l}\text { Hypothesis } \\
\text { Direction }\end{array}$ & $\begin{array}{l}\text { Standardized } \\
\text { Beta-Coeff. }\end{array}$ & $\begin{array}{c}\text { t } \\
- \text { value }\end{array}$ & Result \\
\hline $\mathrm{OC} \rightarrow \mathrm{DE}$ & $\mathrm{H}_{1}$ & + & $0.192^{* * *}$ & 2.6667 & $\overline{\text { Support }}$ \\
\hline $\mathbf{M A} \rightarrow \mathbf{D E}$ & $\mathrm{H}_{2}$ & + & $0.255^{* * *}$ & 2.9310 & Support \\
\hline $\mathbf{A R} \rightarrow \mathbf{D E}$ & $\mathrm{H}_{3}$ & + & $0.236^{* * *}$ & 3.4706 & Support \\
\hline $\mathrm{SE} \rightarrow \mathrm{DE}$ & $\mathrm{H}_{4}$ & - & $-0.154^{* * *}$ & -2.0533 & Support \\
\hline \multicolumn{4}{|c|}{$\begin{array}{l}\chi_{(176)}^{2}=312.933, \chi 2(660) / \mathrm{df}=1.7 \quad, \quad \mathrm{GFI}=0.908, \\
\mathrm{TLI}=0.941, \mathrm{CFI}=0.951, \mathrm{RMSEA}=0.052<.08\end{array}$} & AGFI $=0$ & $\overline{.880,}$ \\
\hline
\end{tabular}

structural models were estimated in this study. One did not include control variables and the other one did. In the model (see Figure1), goodness-of-fit statistics, indicating the overall acceptability of the structural model analyzed, are acceptable. The results are presented in Table 2. There was a satisfactory fit between the proposed model and the data. The estimated standardized path coefficients were used to test each hypothesis. Overall, all the signs of coefficient are consist with the expected signs. The relationship between overconfidence, mental accounting and regret aversion are positive and statistically significant effect on disposition effect. Self-Control is negative and significant effect on disposition effect.

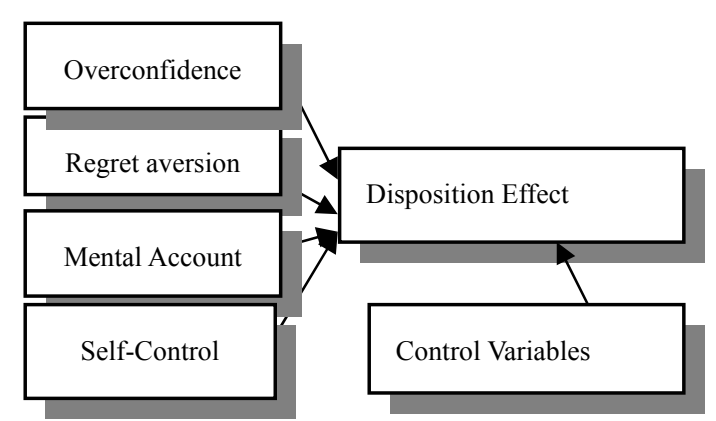

Fig.1 Research Framework 
The second model includes four control variables: gender, age, investment amounts and trading frequency. All the estimated standardized path coefficients of four control variables are not significantly different from zero.

\section{Discussion and Managerial Implications}

This research finds that investor psychology will truly affect investor behavior of selling gain stocks and holding loser stocks. Therefore, investor must recognize this fact and try to practice some mechanisms to control his (her) irrational behavior. Overconfidence occurs when investors overestimate the precision of their private signals and their knowledge about the value of a financial security and always remember the succeed part and easily forget the failure (Odean, 1998). Accordingly, investor should evaluate information objectively to avoid overconfidence. Finally, the higher the self-control is, the less the disposition effect exists. Therefore, investor must try to practice some mechanisms to control his (her) irrational behavior.

\section{Limitations and Suggestion for Future Research}

There are four suggestions for future research: The development of measurement scale, widely sample, other psychology factors, other investment market, the conditions of overall stock market environment. In addition, it is worth to analyze the interactions between these psychological factors such as self-control, overconfidence, regret aversion and mental accounting to clarify the relationships among various psychological factor and disposition effect.

\section{Reference}

[1] F. D.Davis, J. E Kottemann, "User Perceptions of Decision Support Effectiveness: Two Production Planning Experiments." Decision Sciences, 25, pp.57-78, 1994.

[2]B. M.Baraber and T. Odean. "The Courage of Misguided Convictions," Financial Analysis Journal, pp.41-55, 1999.

[3] R. P. Bagozzi, Y. Youjae, L.W. Phillips, "Assessing Construct Validity in Organizational Research." Administrative Science Quarterly 36, pp.421-458, 1991.

[4] B. M.Baraber and T. Odean. "The Courage of Misguided Convictions," Financial Analysis Journal, 41-55,1999.

[5] M. Grinblatt, and M. Keloharju, "What Makes Investors Trade?" The Journal of Finance 56, pp.589-616,2001.

[6] S. Kleinfield, "The Traders." New York: Holt, Rinehart and Winstion, pp.1-10, 1983.

[7] J. E. Kottemann, F. D. Davis, , and W. E. Remus, "Computer-Assisted Decision Making : Performance,
Beliefs, and the Illusion of Control," Organizational Behavior and Human Decision Processes, 51, pp.26-37,1994.

[8] Kuo Min-Hua, Nai-Fong Kuo, Yao-Chu Chiu and Ping-Hang Fan. "Gender and Taiwanese Individual Stock Investros Behavioral" Taiwan Banking and Finance quarterly13, no 2, pp.1-28,2005.

[9] D. Kahneman, and A. Tversky. "Prospect theory : An Analysis of Decision under Risk." Econometrica 46, pp.236-291, 1979.

[10] D. Kahneman, , and D. Lovallo. "Timid choices and bold forecasts: A cognitive perspective on risk taking." Management Science 39, pp.17-31,1993

[11] S. Lichtenstein, B. Fischhoff, and L. D. Phillips, Alibration of probabilities: The state of the art to 1980. In D. Kahneman, P. Slovic \& A. Tversky (Eds.), Judgment under uncertainty: Heuristics and biases, (1982): 306-334. (New York: Cambridge University Press.)Weber, M. and C. Camerer. "The Disposition Effect in Securities Trading: An Experimental Analysis," Journal of Economic Behavior \& Organization 33, pp.167-184,1982.

[12]Lopes, Lola. "Between Hope and Fear: The Psychology of Risk," Advances In Experimental Social Psychology 20, pp.255-295,1987.

[13] T. Odean, "Are Investors Reluctant to Realize Their Losses?" Journal of Finance, 53, pp.1775-1798,1998.

[14] R. E. Pereira, "Factors Influencing Consumer Perceptions of Web-Based Decision Support Systems," Logistics Information Management, 12, pp.157-181,1999.

[15] H. Shefrin, and M. Statement. "Behavioral portfolio theory," Journal of Financial and Quantitative Analysis35, no2, pp.127-151, 2000.

[16]Shefrin, H. and M. Statement. "The Disposition to Sell Winners Too Early and Ride Losers Too Long: The Theory and Evidence," Journal of Finance, 40, pp.777-790,1985

[17] R. J. Shiller, "Measuring Bubble Expectations and Investor Confidence", Reprinted in Journal of Psychology and Financial Markets1, pp.49-60,2000.

[18]T R. H. haler, "Mental Accounting and Consumer Choice." Marketing Science 4, pp.199-241,1985.

[19] A. Tversky, and D. Kahneman. "The Framing of Decisions and the Psychology of Choice," Science 211,pp.450-458,1981.

[20] R. H. Thaler, "Mental Accounting Matters," Journal of Behavioral Decision Making12, pp.183-206,1999.

[21]Zhang, Yuan Fu. "The Study of Southern Taiwan Area Amateur Investors' Disposition Effect in Security Market of Taiwan." (National Ping Tung University of Science and Technology, 2004) 